\title{
Priority of Water Supply Service for Community in Gresik City, East Java Province
}

\author{
Meidyas Riska Wahyuni ${ }^{1}$, Eko Budi Santoso ${ }^{2}$, Haryo Sulistyarso ${ }^{3}$
}

${ }^{1}$ Master Programme of Urban Development Management, Sepuluh Nopember Institute of Technology, Surabaya, Indonesia

${ }^{2,3}$ Lecture Urban Development Management, Faculty of Civil Engineering and Planning, Sepuluh Nopember Institute of Technology, Surabaya, Indonesia

\begin{abstract}
Water supply is one of important aspect and a priority in urban planning. The fulfillment of a water supply necessity for Gresik City is still not optimized. Gresik City consists of 2 districts, namely Gresik District and Kebomas District. Based on ministerial regulation 14/2010, coverage of water supply service at Gresik City was classified as bad with water supply service rate less than 50\%. Hence, for the sake of optimizing and equity of water supply service at Gresik City, the identification of water supply service ratio of Gresik City and community's perception of water supply service was needed. The research objective was to identify water supply service priority for community at Gresik City. The ratio analysis was done by calculation method based on water supply necessity and availability standard. While, the analysis of water supply service based on community's perception was done by descriptive statistical analysis. The results showed that the highest ratio of water supply service was on Kroman Sub-District and the lowest ratio of water supply service was on Tenggulunan Sub-District. Based on community's perception analysis, there are 93\% of Gresik District residents and 75\% of Kebomas District residents that haven't used PDAM (local water supply company) water supply service. Furthermore, water supply service wasn't optimized yet in term of water quality, quantity, continuity, so that the handling of water supply service was focused on sub-district with lowest water supply service ratio.
\end{abstract}

Keywords-Service, water supply, Gresik City, Community.

\section{INTRODUCTION}

Water is a resource that is very much needed by living things, whether it to fulfills their needs or sustains their life naturally. The use of water is universal and thorough on every aspect of life. The higher of life quality of a person, the higher needs of water too (Unus, 1996) ${ }^{[1]}$. Water supply is one of important aspect and a priority in urban planning (Catanese, 1996) ${ }^{[2]}$.Water supply is no longer an available commodity and free to use, but a scarce commodity that needs a proper management $(\text { Kodoatie, 2002) })^{[3]}$.

Local Water Supply Company (PDAM) was carrying out a main task to manage and provides water supply service in order to increase public's welfare as stated on RI Regulation 23/2014 about local government ${ }^{[4]}$. This company was also provided water supply service for Gresik City. Based on Gresik City Spatial Plan 2010 ${ }^{[5]}$, Gresik City was divided into two districts, namely Gresik District and Kebomas District.

Based on PDAM data on 2014, the level of water supply service on Gresik District was 46, 87 1/dt and Kebomas District was 44, 19 1/dt. Based on Ministerial Regulation 14/2010 ${ }^{[6]}$, on the water supply service standard, the water supply service on Gresik City was classified as bad because the level of service was below 50\%. At Gresik District, there were nine subdistricts that classified as bad, namely Sub-district Gapurosukolilo (41\%); Sub-district Bedilan (42\%); Sub-district Kebungson (46\%); Sub-district Pekelingan (27\%); Sub-district Kemuteran (43\%); Sub-district Kroman (48\%); Sub-district Karangpoh (38\%); Sub-district Karangturi (43\%) and Sub-district Tlogopojok (34\%). Whilst at Kebomas District there were 6 sub-districts that classified as bad, namely Sub-district Singosari (30\%); Sub-district Karangkering (6\%); Sub-district Gulomantung (32\%); Sub-district Kedanyang (32\%); Sub-district Tenggulunan (5\%); and Sub-district Kawisanyar (8\%).

Based on consensus on Sustainable Development Goals (SDGs), the target of water supply service at urban areas on 2019 was $100 \%$. In order to make equity of water supply service at Gresik City in accordance with SDGs target, a research about the condition of water supply service was needed, so that the water supply service at Gresik City could be optimized. 


\section{METHODS}

\subsection{Research Variables}

The research variables were obtained from theoretical review and policies review. The research variables and sub variables are mentioned at Table 1

\section{TABLE 1}

RESEARCH VARIABLES

\begin{tabular}{|c|c|c|c|}
\hline${ }^{\text {Aspect }}{ }_{[10][11]}^{[7][8][9]}$ & Indicator & Variable & Definisi Operasional \\
\hline \multirow{3}{*}{$\begin{array}{l}\text { Availability of } \\
\text { Water supply }\end{array}$} & $\begin{array}{l}\text { Water supply } \\
\text { source }\end{array}$ & Water supply source debit & Total debit of water supply source (lt/dt) \\
\hline & \multirow[b]{2}{*}{ Piping condition } & Pipe's length & Pipe's length from transmission to SR (m) \\
\hline & & The age of pipeline network & $\begin{array}{l}\text { Pipeline's age counted from the date it got } \\
\text { installed (year) }\end{array}$ \\
\hline \multirow{4}{*}{$\begin{array}{l}\text { Condition of } \\
\text { water supply }\end{array}$} & \multirow{2}{*}{$\begin{array}{l}\text { Domestic need of } \\
\text { water supply }\end{array}$} & Total population & The number of population (person) \\
\hline & & Daily consumption & The number of water consumption (1/day) \\
\hline & \multirow{2}{*}{ Water leakage } & The amount of water produced & The total of water produced $\left(\mathrm{m}^{3}\right)$ \\
\hline & & Numbers of account recorded & The total of water usage by consumers $\left(\mathrm{m}^{3}\right)$ \\
\hline \multirow{3}{*}{$\begin{array}{l}\text { Water Supply } \\
\text { Service }\end{array}$} & \multirow{3}{*}{$\begin{array}{l}\text { Water supply } \\
\text { service using } \\
\text { pipelines per } \\
\text { household }\end{array}$} & Quality & $\begin{array}{l}\text { Water quality received by community that } \\
\text { could be physically seen based on RI Health } \\
\text { Ministerial Regulation } \\
\text { 416/Menkes/PER/IX/1990, namely clear } \\
\text { water, colorless, odorless, and tasteless. }\end{array}$ \\
\hline & & Quantity & $\begin{array}{l}\text { Water supply debit per household, be } \\
\text { observed by the water supply was smoothly } \\
\text { running or faltered. }\end{array}$ \\
\hline & & Continuity & $\begin{array}{l}\text { Water streamed continuity } 1 \times 24 \text { hours per day } \\
\text { (24 hours or not) }\end{array}$ \\
\hline
\end{tabular}

\subsection{Research Methods}

To obtain water supply ratio analysis results, the first step was to identify the needs and availability of water supply. Water supply necessity was calculated based on the criteria of National Policy and Strategy of Water Supply System Development on Public Works Ministerial Regulation 20/2006 ${ }^{[12]}$ with 120/1/person/day for urban areas and 60 1/person/day for rural areas. Water supply necessity of settlement areas was a domestic water need, which would be calculated upon land area and settlement area. The formula used for the water supply necessity analysis, i.e.:

$$
\text { Water supply necessity }=\mathrm{a} \times \mathrm{b} \times \mathrm{c}
$$

Explanation:

$\mathrm{a}=$ total population (person)

$\mathrm{b}=$ the number of domestic water supply needs based on regions (litre/person/day)

$\mathrm{c}=$ water supply service $(\%$ of total population)

The second step was to identify water supply production capacity which was provided for each sub-district in the research area. Water supply capacity was calculated by multiplying total population covered by water supply service in the area with the daily water supply necessity standard, i.e. 80 litres/person/day. The formula used for the water supply capacity analysis, i.e.:

$$
\text { Water supply production capacity }=\mathrm{a} \times \mathrm{b}
$$

Explanation:

$\mathrm{a}=$ the number of population served by water supply service (person)

$\mathrm{b}=$ average water supply service necessity (litre/person/day) 
After identifying water supply production capacity, the next step was to calculate the ratio of water supply service. The formula to determine the water supply service based on SPM (minimum service standard) formula of water supply availability (Ministerial Regulation 14/2010) ${ }^{[6\}}$, i.e.:

Water supply service ratio $=(\mathrm{a} / \mathrm{b}) \times 100$

Explanation:

$\mathrm{a}=$ water production capacity per month $\left(\mathrm{m}^{3} /\right.$ month $)$

$\mathrm{b}=$ total capacity of community's water supply necessity each month $\left(\mathrm{m}^{3} / \mathrm{month}\right)$

Therefore, the percentage of water supply service debit that got served by local water supply company (PDAM) for each subdistricts at Gresik District were obtained.

In order to identify water supply service based on community's perception, it was done by descriptive statistical analysis. The analysis was based on existing condition by doing interviews based on random sample (purposive random sampling) to the community of Gresik District and Kebomas District. The analysis was utilized for understanding community's perception towards water supply service. Total samples were 200 household. The descriptive statistical analysis was done by using software SPSS for windows.

\section{FINDING AND ARgUMENTS}

\subsection{Characteristic of areas}

The area of research were urban areas at Gresik Region, namely Gresik District and Kebomas District. The main focuses of the research were purred into sub-districts which were stated as urban areas. Thus, the research areas were based on subdistricts which set based on urban area.

The number of population at Gresik District studied were 32,192 people which were divided into 9 sub-district, and the number of population at kebomas district studied were 25,559 people which were divided into 6 sub district. Community served by water supply service in gresik district were $2,977 \mathrm{SR}$, and community served by water supply service in kebomas district were 1,332 SR. The identification of water supply in research area was done first by identifying total population at each sub district, then it was adjusted toward service target to acquired total community served by water supply service. furthermore, the total community served by water supply service was adjusted by average water consumption based on urban areas standard. Based on the result, the water supply necessity at Gresik District was 39.6 1/second, and water supply necessity at Kebomas District was 27,22 1/second

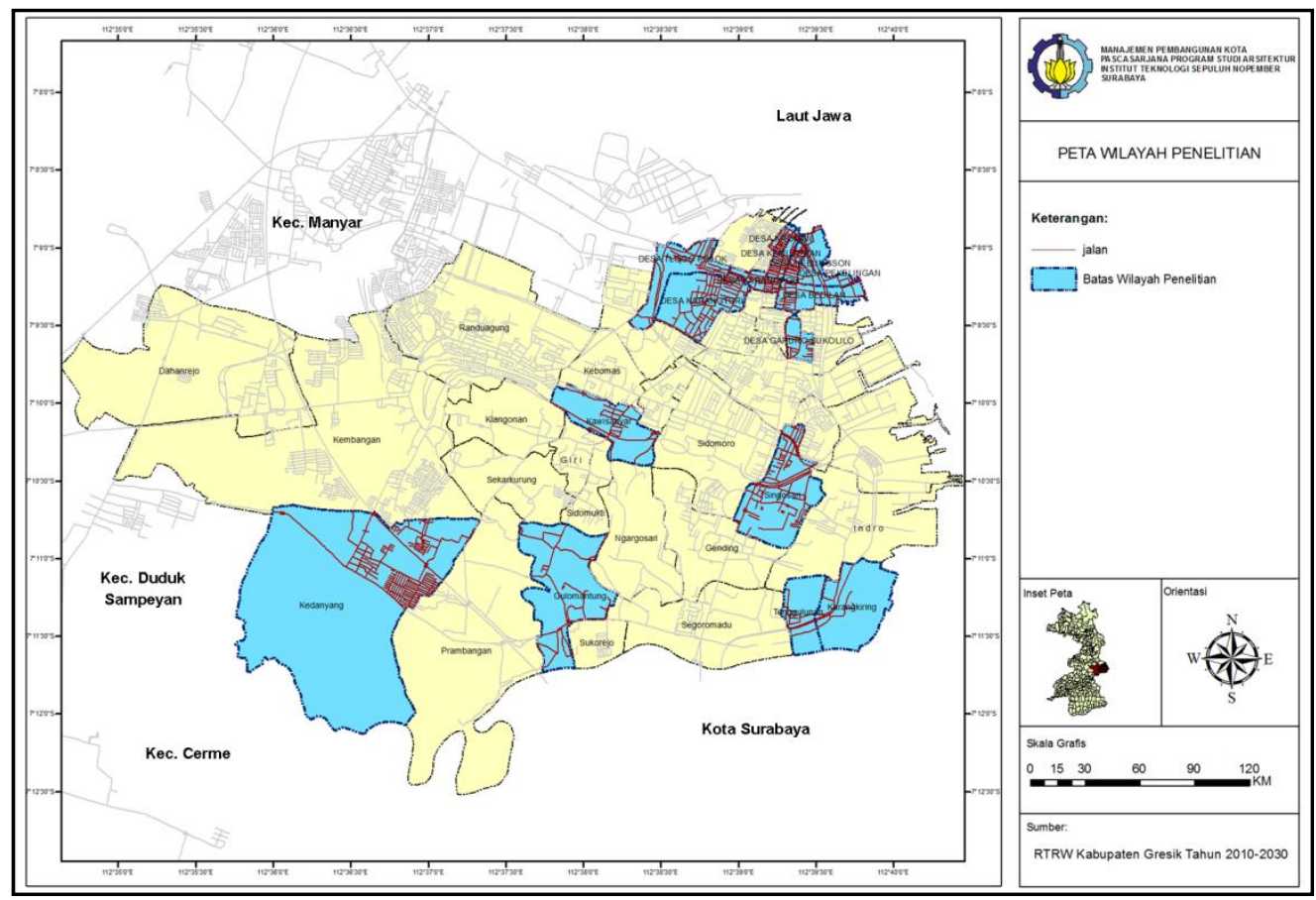

FIGURE 1. RESEARCH AREA ORIENTATION 


\subsection{Water Supply Service Ratio Analysis}

Water supply service at research area was calculated by comparing water supply service availability/ water supply production with community's water supply necessity. The results of level of water supply coverage in research area could be observed on table 2.

TABLE 2

WATER SUPPLY SERVICE RATIO AT RESEARCH AREA

\begin{tabular}{|c|c|c|c|c|c|}
\hline No. & Sub District & $\begin{array}{l}\text { Total Population } \\
\text { Served (person) }\end{array}$ & $\begin{array}{c}\text { Water Supply } \\
\text { necessity (m3/month) }\end{array}$ & $\begin{array}{l}\text { Water Supply } \\
\text { Availability } \\
\text { (m3/month) }\end{array}$ & $\begin{array}{l}\text { Water Supply } \\
\text { Service (\%) }\end{array}$ \\
\hline & & [a] & [b] & [c] & [d] \\
\hline \multicolumn{6}{|c|}{ Gresik District } \\
\hline 1. & Gapurosukolilo & 1,050 & 9,381 & 2,898 & 30.89 \\
\hline 2. & Karangturi & 2,610 & 22,000 & 7,203 & 32.74 \\
\hline 3. & Karangpoh & 1,425 & 13,670 & 3,933 & 28.77 \\
\hline 4. & Bedilan & 1,720 & 14,821 & 4,747 & 32.03 \\
\hline 5. & Kebungson & 1,310 & 10,301 & 3,615 & 35.10 \\
\hline 6. & Pekelingan & 670 & 8,987 & 1,849 & 20.58 \\
\hline 7. & Kemuteran & 895 & 7,489 & 2,470 & 32.98 \\
\hline 8. & Kroman & 2,380 & 17,896 & 6,568 & 36.71 \\
\hline 9. & Tlogopojok & 2,825 & 30,668 & 7,797 & 25.42 \\
\hline \multicolumn{6}{|c|}{ Kebomas District } \\
\hline 10. & Singosari & 2,940 & 36,634 & 8,114 & 22.15 \\
\hline 11. & Karangkering & 70 & 3,915 & 193 & 4.93 \\
\hline 12. & Gulomantung & 900 & 10,485 & 2,484 & 23.69 \\
\hline 13. & Kedanyang & 2,495 & 29,197 & 6,886 & 23.58 \\
\hline 14. & Tenggulunan & 25 & 1,865 & 69 & 3.70 \\
\hline 15. & Kawisanyar & 230 & 10,801 & 635 & 5.88 \\
\hline
\end{tabular}

\section{Explanation:}

$[a]=$ total population at sub-district

[b]= water necessity based on the added capacity to water leakages (m3/month)

$[c]=$ water production capacity

$[d]=$ level of water supply service $=(c / b) * 100 \%$

Based on the calculation, it was discovered that the average of water supply service at Gresik District was 30\% and at Kebomas District was ranged from 5\% to 20\%. The highest ratio of water supply service of Gresik District was on Kroman Sub-District, and the lowest ratio of water at supply service was on Pekelingan Sub-District. The highest ratio of water supply service of Kebomas District was on Gulomantung Sub-District and and the lowest ratio of water at supply service was on Tenggulunan Sub-District.

The high ratio was caused by highly total population, also high water supply necessity and availability if compared with others sub-district, vice versa. The number of population at an area, affecting the level of water supply needs, the more population, the higher needs of water supply.

\subsection{Water Supply Service Based on Community's Perception}

The water supply service analysis was using $200 \mathrm{KK}$ which divide into 113 respondents of Gresik District and 87 respondents of Kebomas District. There are 93\% of Gresik District residents and 75\% of Kebomas District residents that haven't used PDAM (local water supply company) water supply service. Water quality was mostly murky, salty, and wasn't continuously running every day. The condition was causing the community to seek other water supply sources, such as gallon waters and water sellers with carts. 

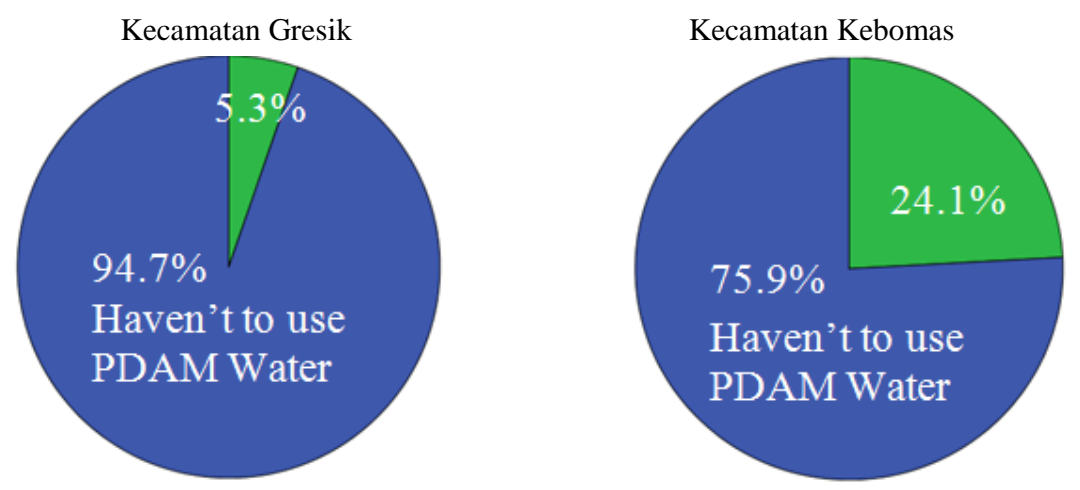

Willingness to use PDAM water
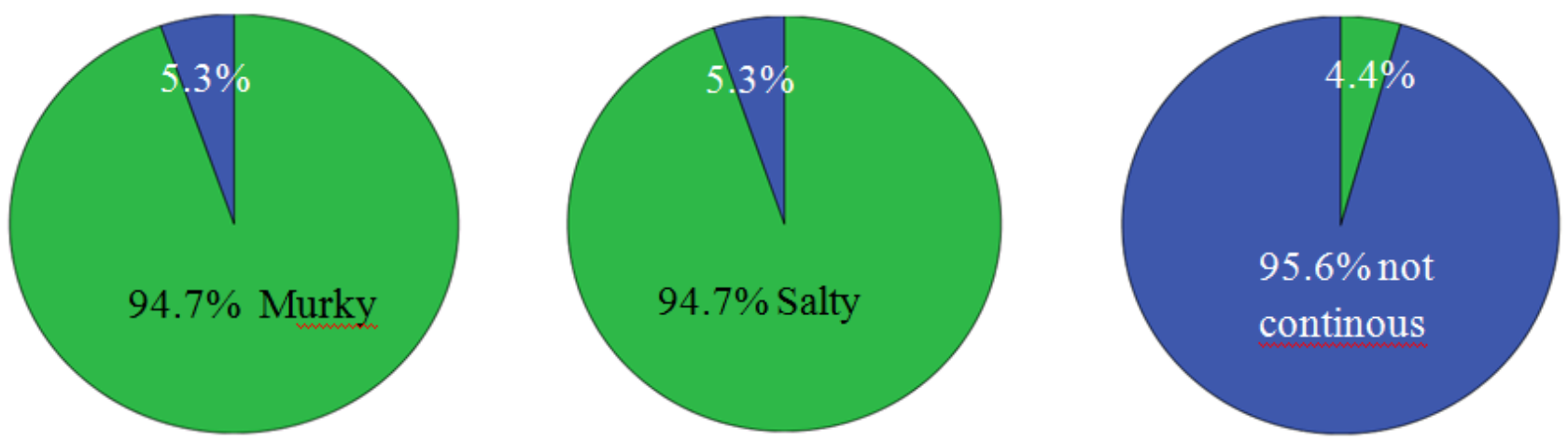

Gresik District community's perception of existing water supply sources (not only PDAM)
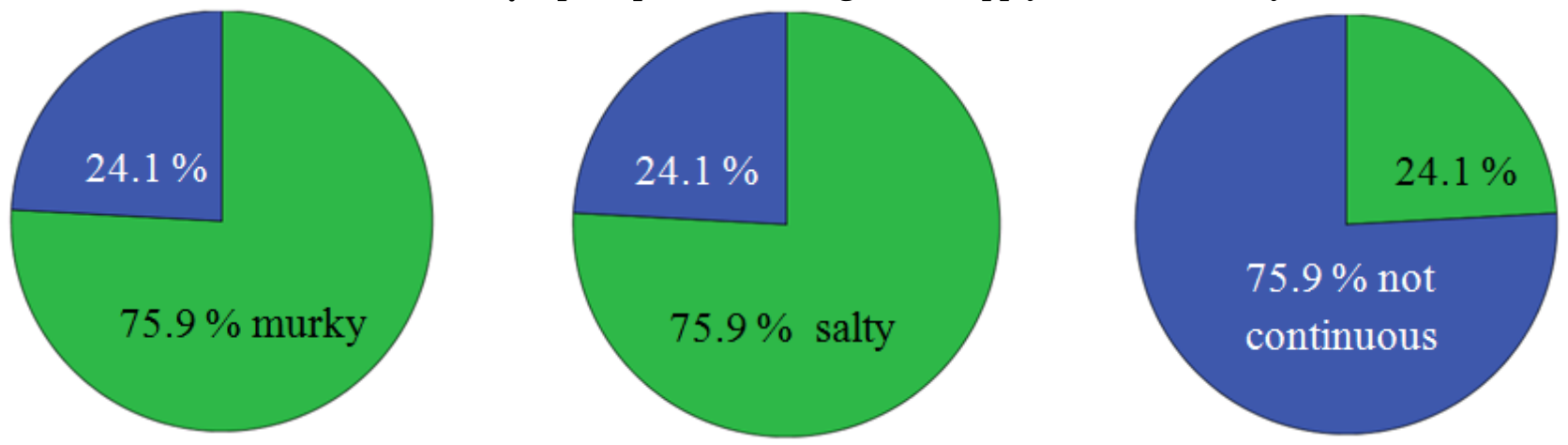

Kebomas District community's perception of existing water supply sources (not only PDAM)

Figure 2. Diagram of Community's Perception toWARds WATER SuPPly SERVICE

\section{CONClusion}

Water supply service priority was done by comparing the results of water supply necessity and availability analysis, with water supply service based on community's perception analysis. The research's conclusion, namely:

1. As a whole, the water supply service on research area hadn't been able to reach the target of clean water service by $100 \%$. The highest ratio of water supply service of Gresik District was on Kroman Sub-District, and the lowest ratio of water at supply service was on Pekelingan Sub-District. The highest ratio of water supply service of Kebomas District was on Gulomantung Sub-District and and the lowest ratio of water at supply service was on Tenggulunan Sub-District.

2. Most of Gresik District's community hasn't used PDAM water supply service (93\%), whereas at Kebomas District, $75 \%$ of community hasn't used PDAM water supply service. Water quality was mostly murky, salty, and not continuously streaming all day. The condition forced the community of Gresik and Kebomas Districts to seek other water supply sources to fulfill their needs, such as using gallon water, and buying water from water sellers with carts.

3. Based on the results, water supply service wasn't optimized yet in term of water quality, quantity, continuity, so that the handling of water supply service was focused on sub-district with lowest water supply service ratio, such as Pekelingan Sub-District and Tenggulunan Sub-District. 


\section{ACKNOWLEDGEMENT}

Praise be to Allah and blessings and greetings to the Prophet Muhammad SAW's so that this journal could be finished well. Big gratitude to people who have helped in completing this journal, father and mother, supervisors for the advice and input during the study, staff from across the district as a respondent that helped to provide the research data. Hopefully, this journal could provide benefits and new information to all parties.

\section{REFERENCES}

[1] Unus, Suriawiria. 2005. Air Dalam Kehidupan dan Lingkungan yang Sehat. Bandung. Penerbit: ALUMNI.

[2] Catanese, Anthony 1996. Perencanaan Kota. Terjemahan. Jakarta. Penerbit Erlangga .

[3] Kodoatie, Robert J dkk. 2002. Pengelolaan Sumber Daya Air Dalam Otonomi Daerah. Yogyakarta: Penerbit ANDI.

[4] Undang-Undang- No. 23 tahun 2014 tentang Pemerintahan Daerah.

[5] RTRW Kota Gresik 2010-2030.

[6] Peraturan Menteri Pekerjaan Umum No. 14 Tahun 2010 tentang Standar Pelayanan Minimal Bidang PU dan Penataan Ruang .

[7] Kristiantina. 2009. Arahan Peningkatan Pelayanan Air Bersih di Kawasan Perbatasan Kota Surabaya-Kabupaten Sidoarjo. Surabaya: Institut Teknologi Sepuluh Nopember.

[8] Noerbambang, Morimura. 1993. Perancangan dan Pemeliharaan Sistem Plumbing. Jakarta. Penerbit : Pradnya Paramita.

[9] Raharjo. 2002. Faktor-Faktor Yang Mempengaruhi Tingkat Konsumsi Air Bersih Di Kota Rembang. Tesis: Universitas Diponegoro Semarang.

[10] Santoso, Hamong. 2006. Kebijakan Infrastruktur Air Bersih dan Kemiskinan. Jurnal Percik. Edisi April: Hal 30.

[11] Tornqvist, Rebecka. 2007. Planning Support for Water Supply And Sanitation. Swedia: Uppsala University.

[12] Peraturan Menteri Pekerjaan Umum No 20 Tahun 2006 tentang Kebijakan dan Strategi Nasional Pengembangan Sistem Penyediaan Air Minum. 